\title{
Analysis of Saving Patterns by Rural Households in Guduru Districts of Oromia National Regional State, Ethiopia
}

\author{
Agassa Gadassa ${ }^{1} \quad$ Adem Kedir $^{2 *}$ \\ 1.Department of Statistics, College of Natural and computational Science, Ambo University \\ P.O. Box 19, Ambo, Ethiopia \\ 2.Department of Agro economics, College of Business and Economics, Arsi University, \\ P.O. Box 193, Arsi Ethiopia
}

\begin{abstract}
Background: Saving level in Ethiopia is very low and little is known empirically about its patterns and determinants. Therefore, this study is aimed at analysis of saving pattern of rural households in Guduru districts. Methods: Primary data were collected from the two districts.196 respondents from Guduru districts using multistage sampling techniques. Results: The study showed that 35.20, 34.69 and $30.10 \%$ of Guduru sample household saves in kind, in cash and both in kind and in cash respectively. Multinomial regression model revealed that social and religious expenditures, distance to market, and distance to financial institutions had negative and significant effect on cash saving of household while dependency ratio had negative and significant effect on both in kind and in cash saving also information access and age of household head had positive effect. Conclusion: The pattern of the nature of saving is an important factor in determining whether the saved amount is utilized for productive purpose or not. This study indicated that rural households' areas mainly use physical forms of saving. However, this saving in physical form in study areas was not assessed by formal financial system of the country. Therefore, the study recommends physical saving of household's should be accessed and encouraged to expand gross domestic saving of the country.
\end{abstract}

Keywords: Household's Saving, Saving Pattern, Guduru District, Multinomial Logistic Regression, Oromia, Ethiopia.

DOI: $10.7176 / \mathrm{JESD} / 10-3-04$

\section{Backgrounds}

Saving have not only been described as a key financial and economic issue but also represent a fundamental deriving force of economic growth and development at large. At micro level, saving serves to mobilize financial resources as capital to start up new or expand existing business. When the concept of micro level is linked to the macroeconomic level, saving mobilization is an avenue for increased capital accumulation, meeting households' basic needs in times of income shortages, meeting precautionary demands for money balances and promoting investment of individuals, firms and government which lead to increase national output, economic growth and development (Mankiw, 2001).

Saving is one of the important variables for economic development that has emerged as the central issue in developing countries at least for two reasons. First, foreign aid inflow to the developing economies has declined during recent years. Second, saving positively affects the growth and development. The greater is the saving rate, the higher is the growth rate a country can attain. For economic development, growth is a must which cannot be achieved without investment or capital accumulation and saving through investment plays vital role in this process (Pollet, 2009).

Saving is very important component which is responsible for combating or meeting any emergency accrued by individuals, households or any corporate agencies. Ethiopia is developing country whose rural households are poor in formal financial institutions, infrastructures and other social service. In rural area, household are farmers so that they save their annual income through crop, livestock and other assets. This may be because of non availability of financial institutions near their residence, market problem, infrastructures such as road, transportation and other related problems (Girma et al., 2013).

They also found evidence that the urban-rural differences in bank use has negligible which suggests that formal finance is not primarily restricted to urban households in Pakistan. But Kulikov et al. (2007) analyzed the determinants of saving on demand side. Making distinction between regular and temporary household income allows the authors to put forward the role of income variability and the different forms of household assets in transition economy (Estonia). Their analysis is based on data from household budget surveys. As in many empirical studies shows, they found that saving rates depend more on transitory income than regular income.

The present study is aimed to;

- To identify the marginal effects and directions of factors of saving patterns;

- To identify determinants of savings in rural households of the district 


\section{Methods}

Study Area

This study was undertaken in district of Oromia national regional state, called Guduru which is one of the district in the Oromia region of Ethiopia. Part of the Horo Guduru Wollega Zone, Guduru district is bordered on the south by Jimma Rare, on the southwest by Jimma Horo, on the west by Lake Fincha, on the Northwest by Abbay Chomen, on the North by the Hababo Guduru, and on the East by the Guder River which separates it from Shewa Zone. This district has latitude and longitude of $09^{\circ} 32^{\prime} \mathrm{N}$ and $37^{\circ} 30^{\prime} \mathrm{E}$ respectively with an elevation of 1969 meters above sea level and the area receives $800-1200 \mathrm{~mm}$ of rainfall per year. The 2007 national census reported a total population for Guduru District to be 98,084 people, of whom 48,848 were men and 49,236 were women; about 6,504 or $6.63 \%$ of its population were urban dwellers (GSCS, 2014).

\section{Data Types, Source and Method of Data Collection}

The study was conducted based on both primary and secondary data. The primary data was collected from selected districts whereas secondary data includes list of households and documented background of households. Data had been collected from selected area using questionnaire administered to households interviewed through trained enumerators starting from February to March 2015. Open and close ended questions were used to allow collection of sufficient information through the language of the households. Multistage random sampling technique has been implemented to explore the saving pattern of the districts, sample kebeles and sample households. From the sampling techniques (Cochran, 1977), the sample size is given as,

$$
n_{h}=n \frac{N_{h}}{N}
$$

Where, ${ }^{n_{h}}$ - is the sample size selected from each kebeles, $N_{h}$ - is the size of the selected kebele and N-Population size of the districts.

$$
\begin{aligned}
& \mathrm{n}=\frac{\frac{\left(Z_{\frac{\alpha}{2}}\right)^{2} * P Q}{d^{2}}}{\left(Z_{\alpha}\right)^{2} * P Q} \\
& 1+\frac{1}{N}\left(\frac{\frac{\alpha}{2}}{d^{2}}-1\right) \\
& n_{o}=\frac{\left(z_{\alpha / 2}\right)^{2} p q}{d^{2}} \quad, \mathrm{q}=1-\mathrm{p}
\end{aligned}
$$

The data were analyzed and presented using both descriptive and inferential statistics. Descriptive statistics includes tabulations, averages, frequencies, percentages, mean, standard deviations, student's t-tests and chi square test were run using STATA 11 Statistical software package. Based on the objectives of the study and the characteristics of the variables, two types of models are used. These are: Multinomial logistic regressions and multiple linear regressions models. Multinomial logistic regression is used to show saving patterns of rural households in the two districts. In this case the dependent, categorical response variable were saving pattern of the rural households which is a polychromous and model is used to show the saving patterns and variables expected to affect it while multiple linear regression models were used to identify the determinants of annual saving amounts of rural households.

\section{Multinomial Logistic Regression Models}

Categorical data are data on dependent variable that can fall in to one of mutually exclusive categories. The econometrics literature focus on modeling a single outcome from categories those are mutually exclusive, where the dependent variable outcome must be multinomial distributed. Analysis is not straight forward, however because there are many different models for the probabilities of the multinomial distribution. These models vary according to whether the categories are ordered or unordered, whether some of the individual-specific regressors vary across the alternatives categories and in some setting, whether the model is consistent with the utility maximization.

Suppose that the utility to a household of an alternative $\mathrm{j}$ is $U_{i j}$, where $\mathrm{j}=0,1,2, \ldots, \mathrm{J}$ from the decision makers' perspective, the best alternative is simply the one that maximizes net private benefit at the margin. In other words, household $\mathrm{i}$ will choose saving pattern $\mathrm{j}$ if and only if $U_{i j} U_{i k}, \forall \mathrm{j} \neq \mathrm{k}$. It is important to note that household's utility cannot be observed in practice. What a researcher observe are the factors influencing the household's utility such as household and personal characteristics and attributes of the choice set experienced by the household. Based on McFadden (1978), a household's utility function from using alternative $\mathrm{j}$ can be expressed as follows: 
$\mathrm{U}($ Choice of $\mathrm{j}$ for household $\mathrm{i})=U_{i j}=V_{i j}+\varepsilon_{i j}$

Where, $U_{i j}$ is the overall utility, $V_{i j}$ is an indirect utility function and $\varepsilon_{i j}$ is a random error term. The probability that the household $\mathrm{i}$ select alternative $\mathrm{j}$ can be specified as:

$$
\begin{aligned}
& P_{i j}=\operatorname{Pr}\left(V_{i_{j}+} \varepsilon_{i_{j}} V_{i_{K}+} \varepsilon_{i_{K}}\right) \\
& P_{i_{j}=\operatorname{Pr}(} \varepsilon_{\left.i_{K}<{ }_{i_{j}} V_{i_{j}} V_{i K}, V_{k \neq i}\right)}
\end{aligned}
$$

Assuming that the error terms are identically and independently distributed, the probability that household chooses alternative $\mathrm{j}$ is explained as follow (Greene, 2003):

$$
P_{i j}=\frac{e^{\beta_{j} X_{i j}}}{\sum_{j=0}^{J+1} e^{\beta_{j} X_{i j}}}
$$

Where, $X_{i j}$ is a vector the $\mathrm{i}^{\text {th }}$ households facing alternative $\mathrm{j},{ }_{j}$ is a vector of regression parameter estimates associated with alternative $\mathrm{j}$. From equation above, we can adapt the MNL model fitting to this study as follows:

$$
\begin{gathered}
\operatorname{Pr}(\text { saving pattern }=j)=\frac{e^{\beta_{j} X_{i j}}}{\sum_{j=0}^{J+1} e^{\beta_{j} X_{i j}}} \\
P_{i j}=\frac{e^{\beta_{j} X_{i j}}}{\sum_{j=0}^{J} e^{\beta_{j} X_{i j}}}
\end{gathered}
$$

The coefficients of explanatory variables on the omitted or base category are assumed to be zero. The probability that base category will be chosen can be shown as follows:

$$
P_{i j}=\frac{1}{1+\sum_{j=1}^{J} e^{\beta_{j} X_{i j}}}
$$

Rural household Yi choose one of the saving patterns which are saving in kind, in cash or both in kind and in cash. Since these saving patterns are mutually exclusive and independent, exactly one of $\mathrm{y}_{0}, \mathrm{y}_{1}, \ldots, \mathrm{y}_{\mathrm{J}}$ will be non-zero. Maximum likelihood estimation is the method used to calculate the logit coefficients. MLE seeks to maximize log likelihood, which reflects how likely it is (the odds) that the observed values of dependent may be predicted from the observed values of the independents.

Hausman Test: MNL model is only applicable if the conditions of Independent Irrelevant Alternative assumption is fulfilled (Greene, 2003). IIA implies that the decision between two alternatives is independent from the existence of more alternatives. The validity of IIA assumption is tested using Hausman specification test.

$$
\mathrm{X}^{2}=\left(\widehat{\boldsymbol{\beta}}_{s}-\widehat{\boldsymbol{\beta}}_{f}\right)^{\prime}\left[\left(\widehat{\boldsymbol{V}}_{s}-\widehat{\boldsymbol{V}}_{f}\right)\right]^{-1}\left(\widehat{\boldsymbol{\beta}}_{s}-\widehat{\boldsymbol{\beta}}_{f}\right)
$$

With $\mathrm{X}^{2}(\mathrm{~K})$, Where $\mathrm{K}=\operatorname{rows}\left(\widehat{\boldsymbol{\beta}}_{s}-\widehat{\boldsymbol{\beta}}_{f}\right)$ where, s indicates estimators based on the restricted (constrained) subsets, $\mathrm{f}$ indicates estimators based on the full set of choices. Therefore, $\widehat{\boldsymbol{\beta}}_{s}$ and $\widehat{\boldsymbol{\beta}}_{f}$ are the respective coefficients, and $\widehat{\boldsymbol{V}}_{s}$ and $\widehat{\boldsymbol{V}}_{f}$ are the respective estimated covariance matrices.

Marginal Effects: For unordered multinomial model, there is no single conditional mean of the dependent variable, instead there are $\mathrm{J}$ alternatives, and we model the probabilities of these alternatives. Interest lies in how these probabilities change as regressors change.

$$
\delta_{j}=\frac{\partial p_{i j}}{\partial x_{i}}=p_{j}=p_{i j}\left[\beta_{j}-\sum_{j=0}^{J}\left(p_{i j}\right)\left(\beta_{j}\right)\right]=p_{i j}\left[\beta_{j}-\bar{\beta}_{i}\right], j=0,1, \ldots, J
$$


Saving Patterns for Guduru Rural households

Table 1. Parameter Estimates and Marginal Effects for Saving Patterns of Households in Guduru District

\begin{tabular}{|c|c|c|c|c|c|c|c|c|c|c|}
\hline \multirow{2}{*}{ Variables } & \multicolumn{5}{|c|}{ In cash saving } & \multicolumn{5}{|c|}{ Saves both in kind and in cash } \\
\hline & $\mathrm{dy} / \mathrm{dx}$ & Coef. & Std. Err. & Z & $\mathrm{P}>|\mathrm{z}|$ & $\mathrm{dy} / \mathrm{dx}$ & Coef. & Std. Err. & $\mathrm{Z}$ & $\mathrm{P}>|\mathrm{z}|$ \\
\hline EXPEND & -.000060 & -.000262 & .0001291 & -2.03 & 0.043 & .000022 & .0000191 & .0001428 & 0.13 & 0.894 \\
\hline AGEHH & .0099617 & .034715 & .0157553 & 2.20 & 0.028 & -.006708 & -.0173169 & .0183447 & -0.94 & 0.345 \\
\hline DRATIO & -.066649 & .0062535 & .2662413 & 0.02 & 0.981 & -.130053 & -.68995 & .282513 & -2.44 & 0.015 \\
\hline DMRKT & -.001097 & .101301 & .0386465 & 2.62 & 0.009 & .0382792 & .254938 & .0435081 & 5.86 & 0.000 \\
\hline SEX* & -.044677 & -.043204 & .7619607 & -0.06 & 0.955 & .0690715 & .3757307 & .8818053 & 0.43 & 0.670 \\
\hline EDUCAN & .0592967 & .1715495 & .1889127 & 0.91 & 0.364 & -.052458 & -.1875316 & .228949 & -0.82 & 0.413 \\
\hline TLU & -.007162 & -.023163 & .0271813 & -0.85 & 0.394 & .0054648 & .0167765 & .0295684 & 0.57 & 0.570 \\
\hline MEMMICRO* & -.064097 & -.530602 & .406306 & -1.31 & 0.192 & -.066411 & -.6288344 & .4541131 & -1.38 & 0.166 \\
\hline LAND & .0083875 & .0369964 & .0969672 & 0.38 & 0.703 & -.002874 & .0041161 & .137629 & 0.03 & 0.976 \\
\hline CREDIT* & .009582 & .099696 & .4488579 & 0.22 & 0.824 & .0531984 & .328151 & .4867895 & 0.67 & 0.500 \\
\hline INFO* & .2841228 & 1.53121 & .4566428 & 3.35 & 0.001 & -.020603 & .7616982 & .5146259 & 1.48 & 0.139 \\
\hline DSINST. & -.028224 & -.106376 & .044296 & -2.40 & 0.016 & -.016141 & -.029758 & .0540455 & -0.55 & 0.582 \\
\hline CDAS & .013170 & -.203932 & .4272943 & -0.48 & 0.633 & -.047567 & -.3574926 & .4713846 & -0.76 & 0.448 \\
\hline $\mathrm{AE}$ & -.009149 & .0218259 & .0877066 & 0.25 & 0.803 & .02534 & .145177 & .0948814 & 1.53 & 0.126 \\
\hline -CONS & - & -4.53305 & 1.774795 & -2.55 & 0.011 & - & -3.42406 & 1.843146 & -1.86 & 0.063 \\
\hline $\begin{array}{l}\text { Number of obs } \\
\mathrm{y}=\operatorname{Pr}(\text { saving } \mathrm{p} \\
\mathrm{y}=\operatorname{Pr}(\text { saving } \mathrm{p} \\
\text { (*) dy/dx is for } \mathrm{c}^{*} \text {. }\end{array}$ & $\begin{array}{l}\text { 6, LR ch12 } \\
\mathrm{n}=\text { saves } i \\
\mathrm{n}=\text { saves } i \\
\text { ete change }\end{array}$ & $\begin{array}{l}=111.76 \text {, } \\
\text { ) (predict } \\
\text { and in ce } \\
\text { mmy varis }\end{array}$ & $\begin{array}{l}>>\operatorname{chi} 2=0 \\
\text { tcome }(1))= \\
(\text { predict, or } \\
\text { from } 0 \text { to } 1\end{array}$ & $\begin{array}{l}00, \mathrm{Lo} \\
89085 \\
\text { me(2) }\end{array}$ & .253813 & & $\mathrm{R} 2=0.26$ & & & \\
\hline
\end{tabular}

Source: Own computation from survey data, 2015.

\section{Results and Discussions}

Expenditure on Social and religious celebration(EXPEND): In Guduru sample households, celebration of social and religious influence the choice of cash saving negatively and significantly at $5 \%$ level of significance for the district. The likelihood of household to save in cash decreases by $0.006 \%$ when household increases the expenditures for celebration of social and religious annually.

Age of household head (AGEHH): Age of household head is positive and significant at 5\% level of significance. Given all variables in the model held constant, the likelihood of the household head to choose financial saving option as compared to the base outcome (saving in kind) was $0.99 \%$ when age of household head increase by one year for Guduru rural households. This result is in line with (Teshome et al., 2013) whose study indicated that as household's age increases by one year the likelihood to save in cash is $1.1 \%$ this because giving the value for cash resource increase with age.

Distance to the main market center (DMRKT): Household's home distance from the main market center also has an effect on the saving pattern of the rural households at $1 \%$ level of significance. Keeping other variables constant the likelihood of household choice to saves in cash decreases by $0.11 \%$ as distance between the residence of household and market center increases by one kilometer but as distance increases with the same amount the likelihood of saving both in cash and in kind increases by $38.2 \%$ (Table 1).

Access to information (INFO): This was found to have positive and highly significant at 1\% level of significance to influence on decision to use in cash saving (Table 1). Given all variables in model kept constant, the likelihood of household head choice of in cash saving increases by $28.4 \%$ relative to bench mark (Table 1 ). This implies that household's saving in cash form increases as their access to information increases since knowledge about the use of financial institutions improves advantage of financial saving. The study is similar with (Rogg, 2000) who stated that Medias like radio and mobile plays a great role in advertizing on what to save, how to save and where to save. Distance to saving institution (DSINST): Distance from saving institution was found to have negative and significant at 5\% level of significance. Given all variables kept constant, the likelihood of the household choice of in cash saving relative to the base category decrease by $2.8 \%$ when the distance between household residence home and saving institution increases by one kilometer (Table 1). This implies that as the household residence far from the saving institution, households prefer another saving mode other than in cash form which is in kind form of saving. The study is in line with (Adeyemo, 2010) who stated transaction cost limit saving pattern.

Dependency ratio (DRATIO): The study revealed that dependent members were negatively and significantly affects the choice of in kind and in cash saving of rural households. The likelihood of the household to save both in kind and in cash decreases by $13.0 \%$ relative to the base category (saving in kind) as one more dependent member will be added to the member.

\section{Limitation of the study}

Oromia region has wide range of diverse agro-ecologies, institutional capacities, organizations and environmental conditions, the result of the study may have limitations to make generalizations and make applicable to country as a whole. However, it may be useful for areas with similar context with the study areas.

Conclusions: Results obtained for Guduru rural households' data using multinomial logistic regression revealed that factors like expenditure on Social and religious celebration influences the choice of cash saving negatively at $5 \%$ level of significance. The likelihood of household to save in cash decreases by $0.006 \%$ when household 
increases the expenditures for celebration of social and religious once. The study revealed that age of household head was positively and significantly affecting cash saving of household. It is shown from result, much of sample household head were middle age group and lifecycle theory tells that saving is high at middle age groups since they get much income during that period and expecting that their income will decline soon latter they save in cash. Household's home distance from the main market center also has a negative effect on in cash saving of rural households at $1 \%$ level of significance. Keeping other variables constant, the likelihood of household choice to saves in cash decreases by $0.11 \%$ as distance between the residence of household and market increases by one kilometer but as distance increases with the same amount the likelihood of saving both in cash and in kind increases by $38.2 \%$.

Access to information was found to have positive and significant influence on in cash saving of households. This implies that household head that has access to information increases his or her in cash saving as information improves their knowledge about the use of financial institutions through media like television, radio, mobile, and other information source.

Another factor affecting saving option of household is that distance from financial saving institutions. Distance from saving institution was found to have negative and significant effect on financial saving of rural households because of transaction costs they pay and also farness from the information about saving institution. Also the study revealed that dependent members were negatively and significantly affecting the choice of in kind and in cash saving of rural households. The likelihood of the household to save both inkind and in cash decreases by $13.0 \%$ relative to the base category (saving in kind) as one more dependent member will be added to the member. Recommendation: The recommendations or policy implications drawn from this study were based on descriptive statistics and econometric models that identify significant variables from the analysis of the data. The pattern of disposition of saving is an important factor in determining how the saved amount is utilized for productive purposes. The proportion of household saving in cash determines the channelization of saving for investment in other sectors of the economy. The volume of investment of saving in physical assets determines the productivity and generation of income in that sector itself. The following recommendation should be given to the respective district:

Government through the Bank of Ethiopia need to pursue favorable policies and regulations to enable financial service providers to broaden their scope of coverage by opening more branches, collaborating with rural and localized banks specially in Guduru district. This will also encourage financial institution to implement personal service provision to enhance the savings and investment functions in the area. Government and individual financial institutions need to consider providing facilities to household heads in order to augment their effort to acquire these assets by constructing roads, media and different infrastructures. Lastly, financial institutions should encourage households to save with them because when people have commitment to financial institutions encourages them to save to free themselves. Government and the District Assemblies should intensify engagement with community in the districts through sensitization, mobilizations and educational programmes for communities to see the need to discipline their spending on socio-cultural events and how savings can help them even in times of financial depression.

\section{Declarations}

Ethics and consent to participate

Ethical approval was obtained from Haramaya University, college of computing and Informatics.

\section{Consent for publication}

Not applicable

\section{Availability of data and materials}

The datasets in which conclusion has taken is available on request.

\section{Competing interests}

The authors declare that they have no competing interests.

\section{Funding}

Sponsored by Haramaya University

\section{Acknowledgement}

The Authors heartily thanks Dr Adem Kedir for his encouragement, suggestions and constructive comments, at overall stage for the accomplishment of this research. Also they would like to extend their gratitude to the Haramaya University for offering opportunity and financial support.

\section{REFERENCES}

Abu Girma, 2004. Determinants of domestic saving in Ethiopia. Prepared for the second international conference on the Ethiopian Economy Association, Addis Ababa, Ethiopia. 
Ahmad, M. and Asghar, T. 2004. Estimation of Saving Behavior in Pakistan Using Micro data. The Lahore Journal of Economics, 9(2).

Ahmed, M. S., 2002. Management in living for senior secondary schools (2nd Ed.). Ghana, Kumasi: Bayoba Graphics Limited.

Ando, A. and Modigliani, F., 1963. The "Life Cycle" Hypothesis of Saving: Aggregate Implications and Tests. American Economic Review, 53, 55-84.

Ang, J. 2009. Household saving behavior in an extended life cycle model: A comparative study of China and India. Journal of Development Studies, 45, 1344-1359.

Bendig, M., Ginsberg, L., and Steiner, S., 2009. Savings, Credit, and Insurance: Household Demand for formal financial services in Rural Ghana. BWPI Working Paper no 76.

Beverly S, Sherraden M (1999). Institutional determinants of saving: implications for low-income households and public policy. Journal of Socio-Economics. 28(4): 457-473.

Beverly, S., Sherraden, M., Cramer, R., Williams Shanks, T., Nam, Y., and Zhan, M. 2008. Determinants of asset holdings, Asset building and low-income families (pp. 89-152). Washington DC: Urban Institute Press.

Bisat A., Mohammad A., EL-Erain., 2006. Growth, Saving and Investment in Arab Economies. IMF Working Paper, pp. 33. Washington, D.C.

Carpenter, S. B., and Jensen, R. T. 2002. Household participation in formal and informal savings mechanisms: Evidence from Pakistan. Review of Development Economics, 6, 314-328.

Chan, Y.B., 2005. Multinomial logistic regression (Biostatistics 305). Singapore Medical Journal, 46: 259-269.

Cochran, W. G., 1977. Sampling Techniques. John Wiley and Sons, New York.

Deaton A. 2005. Franco Modigliani and the Life Cycle Theory of Consumption, Research Program in Development Studies and Center for Health and Wellbeing, Princeton University.

Degu A. 2007, household saving behaviour and determinants of saving in rural saving and credit cooperatives in selected district of Amhara Region, Ethiopia. An MSc thesis presented to the school of graduate studies of Haramaya University, P.135.

Dejene Aredo, 2003. Informal financial institutions: the economic importance of Iddir, Iqqub, and loans, technological progress in Ethiopian agriculture, proceedings of the national workshop on technological progress in Ethiopian Agriculture; November 29-30, 2001. Economic department, faculty of business and economics, AAU; Addis Ababa, Ethiopia.

Desalegn Senbeta., 2008. Determinants of farmer's participation in microfinance institution and their behavior in savings.

Duesenberry, J., 1949. Income, Saving and the Theory of Consumer Behavior. Cambridge, Harvard University Press.

Dupas, P., and Robinson, J., 2009. Savings constraints and microenterprise development: Evidence from a field experiment in Kenya (NBER Working Paper No. 14693), Cambridge, MA: National Bureau of Economic Research. Economies: The Indonesian Case, Economic Development and Cultural Change, Vol. 16, No. 3, April, 1968, pp. 385-403.

FinAccess, 2009. National Survey, 2009: Dynamics of Kenya's Changing Financial Landscape, Financial sector deepening, Nairobi.

Friedman, M.,1957. A Theory of the Consumption Function. National Bureau of Economic Research, General Series No. 63. New Jersey: Princeton University Press.

Girma T., Belay K., Bezabih E., and Jema H., 2013. Determinants of Rural Household Savings in Ethiopia: The Case of East Hararge Zone, Oromia Regional State. Journal of Economics and Sustainable Development, Vol.4, No.3, 2013.

Greene, W.,2003. Econometric Analysis (5th Ed.). New Jersey, Prentice Hall.

GSCS, 2014. Guduru woreda saving and credit service, 2014.

Gujarati, D.N., 2003. Basic Econometrics, 4th edition. Mc Graw-hill, Inc, New York.

HADB, 2010. Haramaya Woreda Agricultural Development Bureau. Haramaya, Ethiopia.

Harrell, F., 2001. Regression Modeling Strategies with Applications to Linear Models, Logistic Regression and Survival Analysis. Springer, New York, ISBN: 0-387-95232-2, pp: 568.

Hausman, Jerry A. and Daniel McFadden,1984."Specification Test for the Multinomial Logit Model." Econometrica 52:1219-40.

Helms, B.,2006. Access for All: Building Inclusive Financial Systems. CGAP/World Bank, Washington, Pp.3537.

Hogarth, J., and O’Donnell, K.,1999. Banking Relationships of Lower-Income Families and the Governmental Trend towards Electronic Payment. Federal Reserve Bulletin, 8(7), 459-473.

Issahaku, H., 2011. Determinants of saving and investment in deprived district capitals in Ghana-a case study of Nadowli in the upper west region of Ghana. Continental J. Social sciences 4: 1-11

Keynes, J.,1936. The General Theory of Employment, Interest and Money. New York: Harcourt, Brace and Co. 
Kelly. A. C. and Williamson G..2009. Household Saving Behaviour inDevelopingEconomies: The Indonesian Case. Economic Development and Cultural Change.

Khalek, T. A., Arestoff, F., De-Freitas, N. E. and Mage, S., 2009. A Micro-econometric analysis of Households Saving determinants in Morocco. 1-18.

Kibet, L., Mutai, B., Ouma, D., Ouma, S., and Owuor, 2009. Determinants of household saving: Case study of smallholder farmers, entrepreneurs and teachers in rural areas of Kenya. Journal of Development and Agricultural Economics, 1(7), 137-143.

Kidane B., 2010. Determinants of Gross Domestic Saving in Ethiopia: a time series analysis. Study Mode.com. Retrieved July17, 2013, from Http:/www.Study Mode.com /essays/ determinants - Of - Gross - Domestic Saving - in -535-269.html.

Kifle T., 2012. Determinants of the saving behaviour of cooperative members survey evidence from Tigrayi region, Ethiopia. Journal of research in economics and international finance (JREIF) 1(5):150-158.

Kiiza, B., and Pederson, G. (2002). Household Financial Savings Mobilization: Empirical Evidence from Uganda. Journal of African Economies 10(4), 390-409

Kiiza, B., and Pederson, G., 2008. Household financial savings mobilization: Empirical evidence from Uganda. Journal of African Economies, 10, 390-409.

Kulikov, D., A. Paabut and K. Staehr, 2007. A Micro econometric Analysis of Household Saving in Estonia: Income, Wealth and Financial Exposure. Working Paper number 8, Estonian National Bank.

Mankiw, N.G., 2001. Principles of economics. 2nd Edition: Harcart College publishers.

MoFED, 2012. Macroeconomic Developments in Ethiopia.

Montgomery, D.C., E. A. Peck and G.G. Vining, 2001. Introduction to Linear Regression Analysis. $3^{\text {rd }}$ edition, John Wiley and Sons, New York.

National Bank of Ethiopia (NBE, 2004). A Study on the Need for Establishing Rural and Urban Micro-financial institutions in Ethiopia, Addis Ababa.

Newman C, Tarp F, Broeck K, Quang C, Khani L., 2008. Household saving in Vietnam: insight form a 2006 rural household survey. Vietnam economic management review. 3(1):34-40

Nga, M.T.,2007. An Investigative Analysis into the Saving Behavior of Poor Households in Developing Countries: With Specific Reference to South Africa. An MSc Thesis Presented to the Department of Economics, University of the Western Cape. South Africa.

Nwachukwu T., and P. Odigie., 2009. What Drives Private Saving in Nigeria. Centre for the Study of African Economies Conference, University of Oxford.

Obayelu D. 2012. Saving bevaviour of rural households in kwara state, Nigeria. Afr.j.Basic.Appl.Sci.4 (4) 115 123.

Pollet, I., 2009. Cooperatives in Africa: the age of reconstruction: synthesis of a survey in nine African countries, Coop-Africa working paper No.7, Dares Salaam: International Labor Office/ILO/.

Rehman H, Faridi Z, Bashir F., 2010. Households Saving Behavior in Pakistan: A Case of Multan District. Pakistan Journal of Social Sciences (PJSS). 30(1): 17-29.

Rehman, H., Bashir, F., and Faridi, M. Z., 2011. Saving behavior among different income groups in Pakistan: A micro study. International Journal of Humanities and Social Science, 1, 268-277.

Robinson, J., 2004. Some thoughts on the idea of sustainable Development. Ecological Economics 48, 369-384.

Rogg, C., 2000. The Impact of Access to Credit on the saving behavior of Micro-entrepreneurs: Evidence from Three Latin American Countries. A paper based on a Thesis submitted to the University of Oxford in June 1999.

Rogg, C., 2006. Asset Portfolios in Africa Evidence from Rural Ethiopia. UNU-WIDER, Centre for the Study of African Economies, University of Oxford. Department for International Development (UK). Research Paper No. 2006/145.

Sabri, M. F., 2010. Savings behavior and financial problems among college students: the role of financial literacy in Malaysia. Cross cultural communication, 6(3), 103-110.

Schultz, T.P.,2005. Demographic Determinants of Savings: Estimating and Interpreting the Aggregate Association in Asia, IZA Discussion Paper No. 1479.

Sinha, D., 1999. Saving-Investment Relationship in Japan and Other Asian Countries,

CJES Research Papers No. 98 - 5.

Sherraden, M. S., Williams Shanks, T., McBride, A. M., \& Sewamala, F. 2004. Overcoming Poverty: Supported saving as a household development strategy (CSD Working Paper 04-13). St. Louis, MO: Washington University.

Touhami, A., A. Florence, M.F. Najat and M. Sabine, 2009. A Micro-econometric Analysis of Households Saving Determinants in Morocco, Université Paris Dauphine.

Viaggi D., Bartolini F., Raggi M., Sardonini L., Sammeth F. and Gomez y Paloma S. 2011. Farm Investment Behaviour under the CAP Reform Process. JRC scientific and technical reports. 